\title{
Mycorrhizal Colonization of Cranberry: Effects of Cultivar, Soil Type, and Leaf Litter Composition
}

\author{
Kevin R. Kosola ${ }^{1}$ and Beth Ann A. Workmaster \\ Department of Horticulture, 1575 Linden Drive, University of Wisconsin, Madison, WI 53706
}

\begin{abstract}
AdDITIONAL INDEX words. Vaccinium macrocarpon, ericoid mycorrhizal fungi, decomposition, Ericaceae, symbiosis
Abstract. Although ericoid mycorrhizal fungi improve nitrogen (N) nutrition of cranberry (Vaccinium macrocarpon Ait.) and other Ericaceae in their native habitat, the prevalence of ericoid mycorrhizal colonization in cranberry has not been widely examined. The authors measured ericoid mycorrhizal colonization of cranberry root samples from 13 cultivars growing in cranberry beds in Wisconsin. Mycorrhizal colonization was present in all samples. Bed age had a slight but statistically significant negative effect on mycorrhizal colonization. Neither cultivar, bed substratum, nor soil pH had a significant effect on mycorrhizal colonization. Fungicide treatment for fruit diseases did not appear to affect mycorrhizal colonization of cranberry roots. Soil layering in the root zone incited by regular sanding had a significant effect on mycorrhizal colonization; colonization decreased with increasing depth in the root zone soil. Leaf litter was more decomposed in deeper soil layers, with a lower carbon-to- $\mathrm{N}$ ratio. Given the consistent presence of ericoid mycorrhizal fungi in cultivated cranberry, it is possible that they may play a role in $\mathrm{N}$ nutrition of the cranberry agroecosystem.
\end{abstract}

Cranberry and other members of the Ericaceae commonly form ericoid mycorrhizal (ERM) associations with fungi [e.g., Rhizoscyphus ericae (D.J. Read) W.Y. Zhuang and Korf [syn. Hymenoscyphus ericae (D.J. Read) Korf and Kernan] (Allen et al., 2003; Berch et al., 2002; Read, 1983). Mycorrhizal cranberries can acquire organic forms of nitrogen $(\mathrm{N})$ that would otherwise be unavailable to the uncolonized plant (Bajwa et al., 1985). This ability to use organic $\mathrm{N}$ is likely to increase plant fitness in the native peat bog habitat of cranberries, where organic matter decomposition and $\mathrm{N}$ mineralization is usually quite limited (Malmer et al., 2003; Svensson, 1995).

Despite the extensive literature on cranberry-ERM associations based on tissue culture or greenhouse studies (e.g., Byrne and Mitchell, 2004; Hashem, 1995; Myers and Leake, 1996; Straker and Mitchell, 1986; Stribley and Read, 1976; Stribley et al., 1975), there is little information on the prevalence of ERM colonization of cranberry growing in its native environment or in plantings managed for fruit production. Scagel (2003) has found significant levels of ERM colonization in Oregon commercial cranberry beds, all planted to the cultivar Stevens and growing in beds based on a well-drained sand substrate. Ericoid mycorrhizal colonization in commercial cranberry beds in Oregon can reach levels greater than $90 \%$ root length (Scagel, 2003). Root length colonized gradually increased with increasing bed age, with low colonization $(7.5 \%)$ in beds less than 10 years old, $28 \%$ colonization in 10 - to 12 -year-old beds, $70 \%$ colonization in 15- to 21-year-old beds, and colonization greater than $90 \%$ in 32- to 38-year-old beds (Scagel, 2003).

Soil conditions may affect mycorrhizal colonization in cranberry production. Cranberry bed soils are highly modified by cranberry bed construction and by horticultural practices

Received for publication 16 June 2006. Accepted for publication 28 Sept. 2006. This work was partially supported by the Robert and Helen Gottschalk Endowment and by the Wisconsin Cranberry Board.

We thank Dana Baumann, Calvin Leitzow, Shaminder Miranpuri, Drew Hohensee, and Meghan McLean for technical assistance, and we thank the Wisconsin cranberry growers who allowed us to sample roots on their cranberry marshes.

${ }^{1}$ Corresponding author. E-mail: kkosola@wisc.edu
(Davenport and DeMoranville, 1993; Eck, 1990). Wisconsin cranberry beds are typically prepared by removing vegetation and surface layers of soil to expose a substratum free of roots from existing vegetation (Eck, 1990). Based on grower records, the substrata found underneath Wisconsin cranberry beds are typically composed of either sand or organic soils (peat or muck); single beds may have both types present. During bed construction, a layer of sand (about $30 \mathrm{~cm}$ ) is typically placed on top of the substratum, and stem cuttings are planted into the sand. Because of this practice and the shallow rooting depth typical of cranberry, sand is the predominate material in the root zone of most Wisconsin cranberry beds. As the bed ages, the composition of the root zone soil changes. Wisconsin cranberry growers apply from 1 to $2.5 \mathrm{~cm}$ sand to the beds every 3 to 5 years during the winter (Eck, 1990). Because cranberries are a low-growing perennial with an extensive network of prostrate woody stems growing along the soil surface ("runners"; Roper and Vorsa, 1997), regular sanding produces a soil with alternate layers of sand and organic matter (Fig. 1). Organic matter layers include roots, leaf litter, and stems. Leaf litter accumulates on the surface during the 3- to 5-year interval between sandings; layers deeper in the soil profile thus contain increasingly older leaf litter. This increase in litter age with depth is similar to what would be seen in an undisturbed organic horizon in a forest soil (in the absence of earthworm activity or other mixing), but with a well-defined age range for each layer.

We hypothesized that the substratum beneath the cranberry bed would influence cranberry ERM colonization. Nitrogen fertilization requirements vary among substrate types. Beds with an organic substratum require less $\mathrm{N}$ than beds with a sand substratum, because of $\mathrm{N}$ mineralization of the organic matter in the substratum (Davenport and DeMoranville, 2004; Davenport and Patten, 2002; Eck, 1990). These differences in N availability may affect colonization rates in cranberry beds, because laboratory studies indicate that high $\mathrm{N}$ availability can suppress ERM colonization of cranberry (Bajwa and Read, 1986; Leake et al., 1990; Read, 1996; Stribley and Read, 1980).

Fungicide applications may also influence ERM colonization, because many of the fungicides used in cranberry 


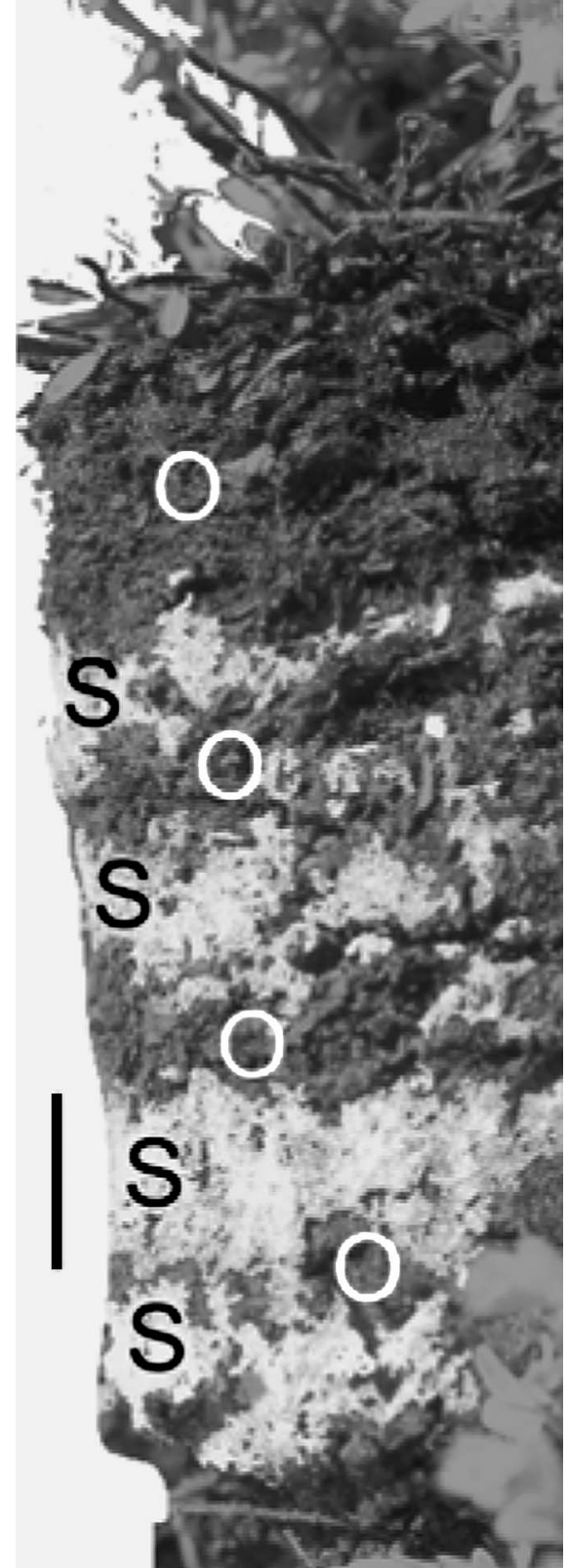

Fig. 1. Soil core from 54-year-old cranberry bed. Alternative organic (O) and sand (S) layers resulted from periodic sanding on top of accumulated leaf litter, stems, and roots. The top organic layer was thicker than typically found in cranberry beds because of an extended period without sanding (resulting from planned bed renovation). Scale $b a r=1.6 \mathrm{~cm}$.

production have broad-spectrum activity (P. McManus, pers. comm., Jan. 2005). Cranberry growers may apply fungicides for a wide range of pathogens that cause root, shoot, and fruit diseases (Caruso and Ramsdell, 1995). We expected to see lower rates of ERM colonization on farms where fungicides were applied.

We expected to see a positive relationship between bed age and ERM colonization in Wisconsin, as had been found in Oregon for 'Stevens' cranberry (Scagel, 2003). We also expected to see variation among cranberry cultivars in ERM colonization, particularly between the modern hybrids and older selections from the wild. Selection for cranberry growth in fertilized conditions might lead to lower dependence upon
ERM fungi for $\mathrm{N}$ nutrition. We carried out a survey of ERM colonization in Wisconsin cranberry beds with a wide range of ages, cultivars, and substratum composition (ranging from organic to sand). We also examined the relationship between ERM colonization and root zone soil layer depth.

\section{Materials and Methods}

Sample Locations and Dates. We collected soil samples from cranberry farms in Wisconsin for an initial broad survey of ERM colonization, for an analysis of the effects of layering resulting from sanding (Figs. 1 and 2) on ERM colonization, and for an analysis of leaf litter composition in soil layers. Samples were collected at three different times; midsummer 2002, midsummer 2004, and fall 2004 (Table 1).

The initial survey of ERM colonization in Wisconsin was based on soil cores collected from eight different commercial cranberry farms within a 2-week period in midsummer 2002 (18-21 June and 2-3 July 2002). These farms were chosen to provide a range of cultivars (Table 2), substrata, soil $\mathrm{pH}$ (Table 1), and geographic locations within the state's cranberry-growing areas (locations available from authors). In each bed (typically rectangular), we collected three $15-\mathrm{cm}$-deep, 6-cm-diameter soil cores on a transect along the length of the bed, centered on the short axis of the bed. Samples were collected at distances $25 \%, 50 \%$, and $75 \%$ of the total bed length. The relationship between bed age and number of organic layers in a 15-cm-deep soil core sample was determined from a subset (randomly selected within 5-year age classes) of the archived, frozen, soil cores from the survey.

Mycorrhizal colonization was analyzed by layer in samples collected in 2002 and 2004 (Table 3). The largest set of samples used in this analysis were collected from a single bed containing cultivar trial plots established at farm 3 (Table 1) in 1980 and 1985. The plots were $5.5 \times 5.5-\mathrm{m}$ square plots arranged in a completely randomized design, separated by bare soil alleyways $\approx 2 \mathrm{~m}$ wide. Bare soil alleyways have been maintained by cultivation on a regular basis. Intact $15-\mathrm{cm}$-deep, $6-\mathrm{cm}$ diameter soil cores were sampled near the center of each plot.

Further sampling and analysis of soil layer effects on ERM colonization was also carried out on samples from additional

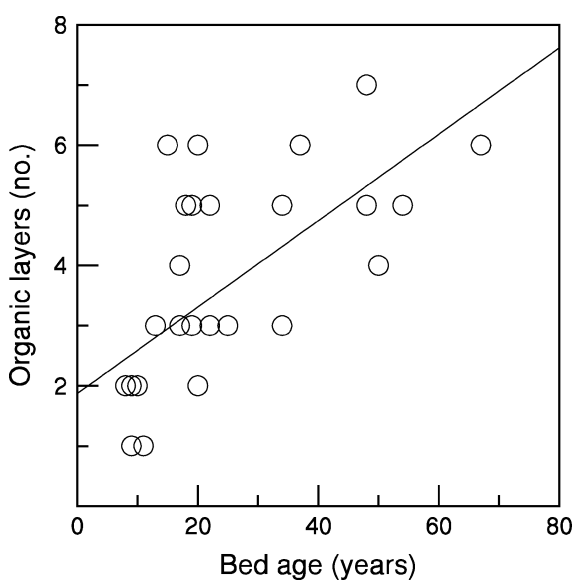

Fig. 2. Number of organic layers observed in 15-cm-deep soil cores as a function of bed age. Cores from six different cranberry farms in Wisconsin in 2002 (farms 1, 2, 3, 4, 6, and 8; Table 1). 
Table 1. Characteristics of cranberry farms sampled in Wisconsin for ericoid mycorrhizal colonization. ${ }^{\mathrm{z}}$

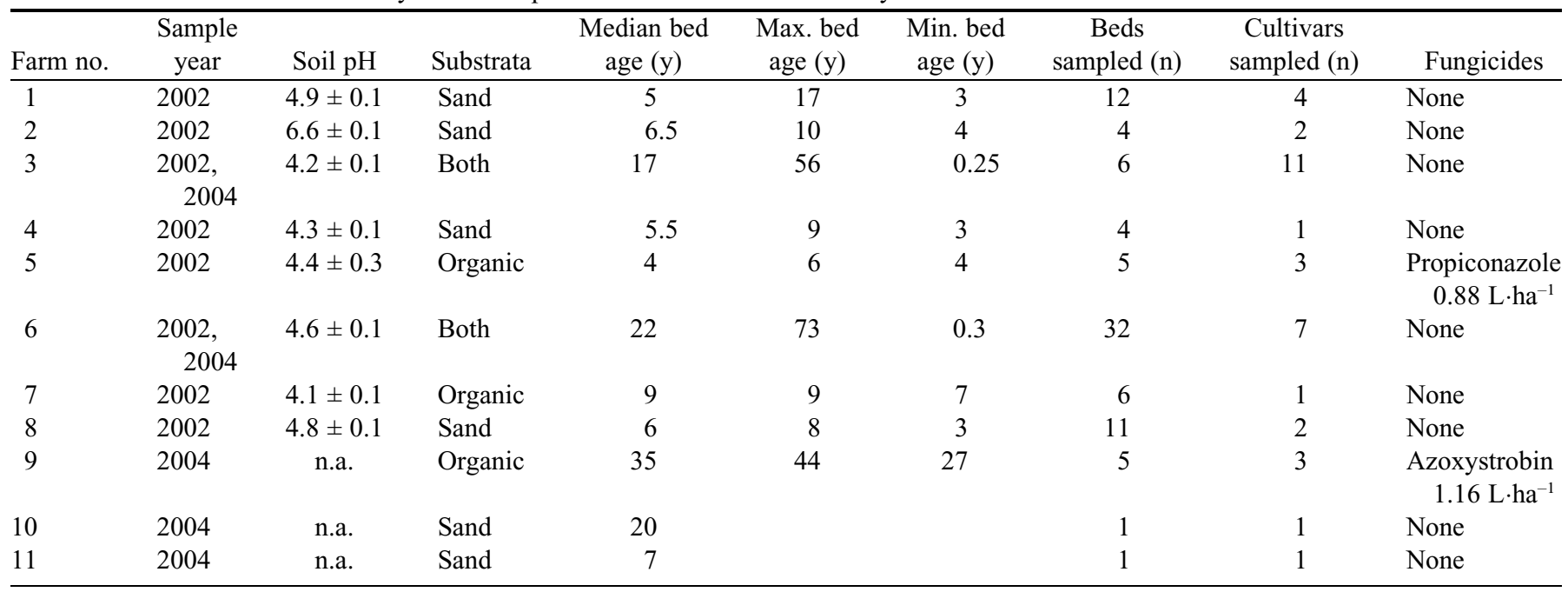

n.a., not available.

${ }^{z}$ Data on soil $\mathrm{pH}$ is from soil cores sampled for colonization measurements. All other information is from grower records. Farms 10 and 11 are under organic management. Farm 11 is in transition to organic certification.

farms. We sampled roots by layer from frozen 'Ben Lear' soil cores archived in 2002 (farms 1 and 6), and from 'Stevens' cores collected in 2004 (farms 3, 9, 10, and 11).

SAMPLES FROM WILd POPUlations. In Nov. 2004, we sampled three populations of wild cranberries near farm 9. One population was in a floating sphagnum bog within $200 \mathrm{~m}$ of the sampled cultivated beds, and two populations were in sphagnum beds in a tamarack swamp [wetland dominated by Larix laricina (Du Roi) K. Koch] within $1 \mathrm{~km}$ of the cultivated beds. We collected three samples per location.

Sample Processing. Each soil core was split in half longitudinally in the field. Soil cores were placed in plastic bags and kept on ice for up to $2 \mathrm{~d}$ after collection, and then transferred to a $4{ }^{\circ} \mathrm{C}$ room. Cores were stored for up to 3 weeks after collection before processing. One longitudinal half core was archived in $\mathrm{a}-20^{\circ} \mathrm{C}$ freezer, and the other half was used for analyses. A subsample (approximately one eighth of the half core, $40 \mathrm{~g}$ dry weight) was split longitudinally from the half core, dried at $50{ }^{\circ} \mathrm{C}$, and used for $\mathrm{pH}$ measurement. Soil $\mathrm{pH}$ was measured after adding deionized water to the dry soil in a $1: 1$ ratio $(\mathrm{w} / \mathrm{v})$, mixing, and allowing to settle for $30 \mathrm{~min}$. The remainder of the core was washed with a high-pressure ( $\approx 483 \mathrm{MPa}$ ) water spray on a $1-\mathrm{mm}$ sieve, with loose roots and other floating organic matter captured by pouring wash water through a $106-\mu \mathrm{m}-\mathrm{mesh}$ sieve. Plant litter (primarily leaves, with some dead stems) was removed and discarded, and roots were separated from stems. The roots were blotted dry with a paper towel and placed in $50 \%$ ethanol at $4{ }^{\circ} \mathrm{C}$ until analysis of colonization (4-12 months after collection). Roots within each core were well mixed before subsampling for analysis of colonization.

SOIL LAYERING EFFECTS ON COLONIZATION. The intact cores were stabilized by running several bamboo skewers longitudinally through each core. Leaf litter was sampled from the edge of each organic layer for analysis. The sand layers were washed away, leaving the stack of organic layers stabilized in their original relative positions with $\approx 1-\mathrm{cm}$ gaps in between. Each layer was distinct, as a result of the high rooting density within the organic layer and the extremely low rooting density in the sand layer. Each washed core was placed in a $0.96-\mathrm{L}$ glass jar with $50 \%$ ethanol and stored at $4{ }^{\circ} \mathrm{C}$. Within each core, roots from each layer were subsampled at three locations on the edge of the core, and the subsamples were bulked before analysis of ERM colonization. The number of distinct layers we could distinguish differed slightly among cores.

Measurement of ERM colonization. Samples were cleared and stained using the methods described in Scagel (2003) and Grace and Stribley (1991). Root length colonization (percent

Table 2. Cranberry cultivars sampled in 2002 for analysis of effects of cultivar, bed age, substrata, and root zone soil pH on ericoid mycorrhizal colonization (percent root length).

\begin{tabular}{|c|c|c|c|c|c|c|c|}
\hline Cultivar & Origin & $\begin{array}{c}\text { Minimum } \\
\text { bed age }(y)\end{array}$ & $\begin{array}{c}\text { Median } \\
\text { bed age }(y)\end{array}$ & $\begin{array}{l}\text { Maximum } \\
\text { bed age }(y)\end{array}$ & $\begin{array}{c}\text { Cores } \\
\text { sampled (n) }\end{array}$ & $\begin{array}{c}\text { Beds } \\
\text { sampled (n) }\end{array}$ & $\begin{array}{c}\text { Farms sampled } \\
\text { (identification no.) }\end{array}$ \\
\hline Ben Lear & Native, Wisc. & 4 & 12 & 34 & 33 & 11 & $1,3,5,6,8$ \\
\hline Bergman & Hybrid & 3 & 7 & 11 & 9 & 3 & 6 \\
\hline LeMunyon & Native, N.J. & 4 & 5 & 11 & 9 & 3 & 1 \\
\hline McFarlin & Native, Mass. & 16 & 50 & 73 & 33 & 11 & 3,6 \\
\hline Pilgrim & Hybrid & 4 & 6 & 19 & 21 & 7 & $1,2,5,6$ \\
\hline
\end{tabular}


Table 3. Cranberry cultivar identity and sampling date of soil cores collected for analysis of effects of layer depth on ericoid mycorrhizal colonization (percent root length). ${ }^{\mathrm{z}}$

\begin{tabular}{|c|c|c|c|c|c|c|}
\hline Sample date & Cultivar & Origin & Replicates & $\begin{array}{c}\text { Cores } \\
\text { (no./replicate) }\end{array}$ & $\begin{array}{c}\text { Farm } \\
\text { (identification no.) }\end{array}$ & Sample age (y) \\
\hline July 2002 & Bain10 & Hybrid & 2 plots & 1 & 3 & $17-22$ \\
\hline July 2002 & Beckwith & Hybrid & 3 plots & 1 & 3 & $17-22$ \\
\hline July 2002 & Franklin & Hybrid & 3 plots & 1 & 3 & $12-17$ \\
\hline July 2002 & Howes & Native, Mass. & 3 plots & 1 & 3 & $12-22$ \\
\hline July 2002 & McFarlin & Native, Mass. & 3 plots & 1 & 3 & 22 \\
\hline July 2002 & Stevens & Hybrid & 1 plot & 1 & 3 & 22 \\
\hline July 2002 & WSU41 & Hybrid & 2 plots & 1 & 3 & 22 \\
\hline July 2002 & WSU61 & Hybrid & 2 plots & 1 & 3 & 17 \\
\hline July 2002 & Ben Lear & Native, Wisc. & 6 beds & 3 & 1,6 & $12-34$ \\
\hline June 2004 & Stevens & Hybrid & 4 farms & 3 & $3,6,10,11$ & \\
\hline Nov. 2004 & Stevens & Hybrid & 3 beds & 2 & 9 & $29-34$ \\
\hline
\end{tabular}

${ }^{\mathrm{z}}$ Samples collected from farm 3 in July 2002 were from a single bed containing a cultivar trial. Plots were at least $5.5 \times 5.5 \mathrm{~m}$.

root length containing ERM structures), was measured by a line intercept method (Giovannetti and Mosse, 1980) at 40 to $90 \times$ magnification, using a dissecting microscope.

Leaf litter analysis. Leaf litter samples from each layer were dried in a $70^{\circ} \mathrm{C}$ oven for $48 \mathrm{~h}$ and stored in a desiccator until processed. Leaf litter was hand separated from sand and other organic matter and ground in a miniature ball mill (Wigg-LBug; Crescent Dental Manufacturing, Lyons, Ill.). Litter percent carbon (C) and percent $\mathrm{N}$ (dry weight basis) were analyzed using dry combustion (Bremner, 1996; Nelson and Sommers, 1996) on a Carlo-Erba elemental analyzer (CE Elantech, Lakewood, N.J.).

Statistical analysis. Normality of data were analyzed by SAS Proc UNIVARIATE (SAS Institute, Cary, N.C.). The survey data (Table 2) were analyzed as a mixed model analysis of variance (ANOVA), using SAS Proc MIXED. Cultivar and substrate were treated as fixed variables. Farm was treated as a random variable; individual cores were nested within the interaction for bed, block (based on grower management unit blocking), and farm, and treated as random variables. Both core soil $\mathrm{pH}$ and bed age were used as covariates.

The cultivar planting at farm 3 was organized as a completely randomized design. Colonization data and leaf litter composition data collected from individual layers of intact cores were analyzed as a mixed-model ANOVA, with cultivar as a fixed variable, layer number (nested within core) used as a covariate, and the individual core treated as a random variable. Additional analyses were carried out using litter C-to-N ratio as a covariate. Regression analyses were carried out in CoStat (CoHort Software, Monterey, Calif.).

\section{Results}

Survey. Ericoid mycorrhizal colonization in the Wisconsin cranberry beds we sampled was variable $(11 \%$ to $71 \%$ root length colonization), but present in all beds (Figs. 3 and 4). Ericoid mycorrhizal colonization data were normally distributed with homogenous variation among cultivars, substrates, and bed age (data not shown). Ericoid mycorrhizal colonization declined slightly but significantly with increasing bed age (Fig.
3 ; colonization $=43.98-0.18 \times$ age $\left.\mathrm{F}_{1,182}=4.67, P=0.03\right)$. It is noteworthy that the highest colonization rates were observed in very young beds (Fig. 3). ERM colonization was not significantly affected by $\mathrm{pH}\left(\mathrm{F}_{1,182}=0.07, P=0.79\right)$, by substrate type $\left(\mathrm{F}_{2,182}=1.03, P=0.36\right)$, or by cultivar (Fig. 3; $\left.\mathrm{F}_{7,182}=1.39, P=0.21\right)$.

On one of the Wisconsin farms sampled in 2002 (farm 5), the fungicide propiconazole was applied every year $\left(0.88 \mathrm{~L} \cdot \mathrm{ha}^{-1}\right)$ for control of the fruit disease cottonball [Monilinia oxycocci (Woronin) Honey]. Average ERM colonization on that farm was $52 \%$, which was not significantly different from the other Wisconsin farms sampled that year $(P>0.05)$. The fresh-fruit farm sampled in 2004 (farm 9, Table 1)was treated with 1.16 $\mathrm{L} \cdot \mathrm{ha}^{-1}$ of the fungicide azoxystrobin every year for control of fruit rot. Average colonization of roots in the top layer was $42 \%$ (Fig. 4C), which was not significantly different from colonization in the top layer of beds of similar age grown without fungicides $(P>0.05$; sampled in 2002).

LAYER AGE EFFECTS ON COLONIZATION AND LEAF LITTER COMPOSITION. Layering was pronounced in all Wisconsin cores older than 5 to 10 years (Figs. 1 and 2), because of the practice of applying about 1 to $2.5 \mathrm{~cm}$ of sand to the beds every 3 to 5 years. Roots grew in dense mats within the litter layers, with roots mixed with sand grains, leaf litter, and stems (both live and dead). Few roots were observed in the sand layers. Roots in the youngest beds were distributed throughout the first 5 to $10 \mathrm{~cm}$ of sand. As expected, the number of layers observed within soil cores increased as bed age increased (Fig. 2).

There was a significant $(P<0.05)$ negative correlation between the source layer for root samples and mycorrhizal colonization in all soil cores sampled by layer collected in 2002 and in 2004, except for the 'Stevens' samples from June 2004 (Fig. 4) and the single 'Crowley' bed sampled in Nov. 2004. There was no significant cultivar effect on colonization in any of the sample groups (Fig. $4 ; P>0.05$ ).

Within the samples from the cultivar trial plots sampled in 2002 (farm 3), the C-to-N ratio of leaf litter was not significantly different among the cultivars $\left(\mathrm{F}_{10,61}=1.09, P=0.38\right)$, but decreased significantly with increasing depth in the soil (Fig. 5). Colonization decreased significantly with increasing 


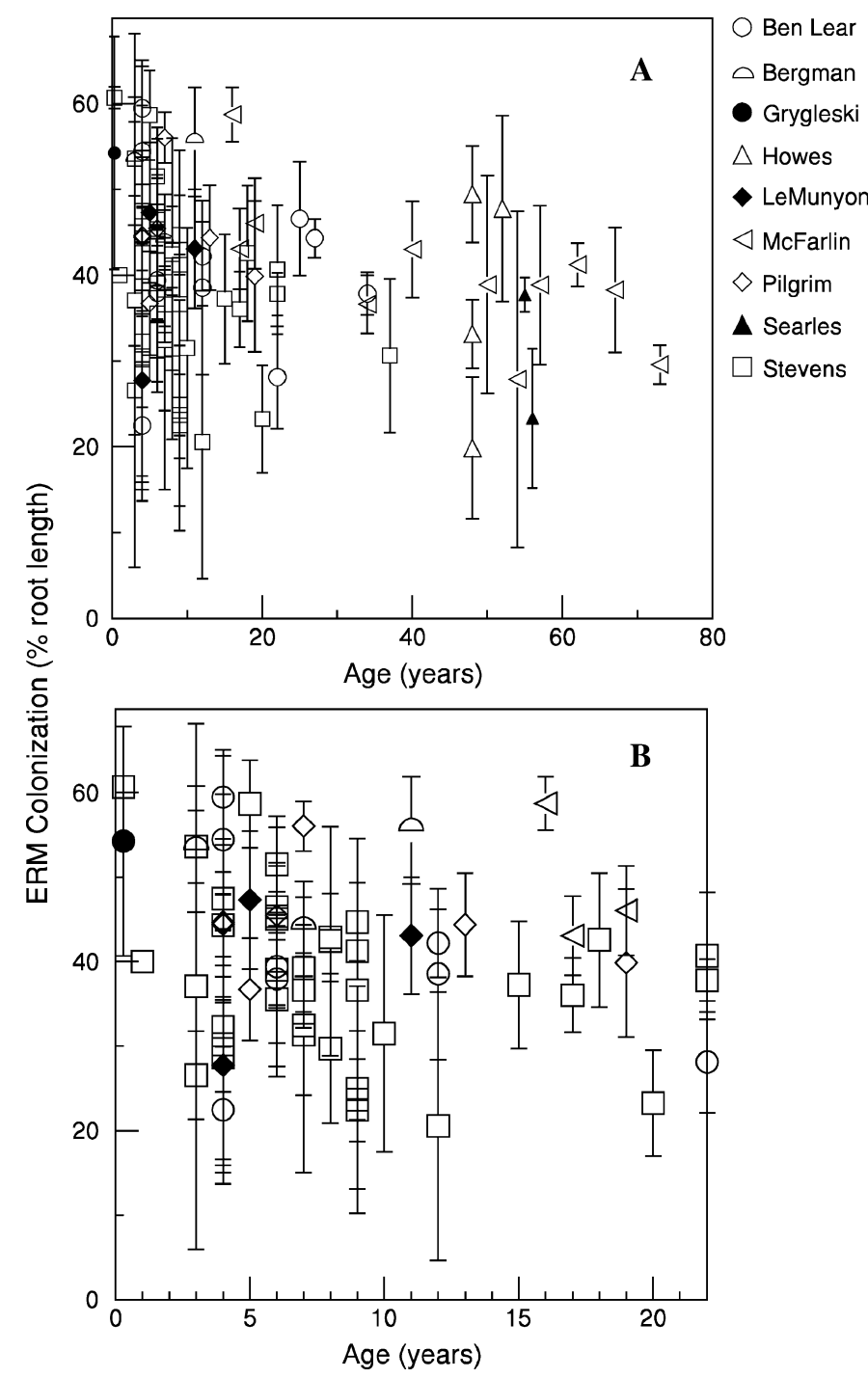

Fig. 3. Effect of bed age (years) on ericoid mycorrhizal (ERM) colonization (percent root length) of cranberry. Data from root samples collected from cultivated beds across eight different cranberry farms in Wisconsin in 2002 (farms 1-8, Table 1). (A) Complete data set; age, 4 months to 73 years. (B) Detail of data set; age 4 months to 22 years. Points represent mean colonization within a single bed; error bars are $\pm \mathrm{sE}, \mathrm{n}=3$.

layer depth $\left(\mathrm{F}_{28,52}=3.60, P=0.001\right)$ with a decreased litter C-to-N ratio $\left(\mathrm{F}_{1,52}=15.92, P=0.0002\right)$.

\section{Discussion}

Ericoid mycorrhizal colonization declined slightly with increasing bed age in Wisconsin cranberry beds, in contrast to Oregon cranberry beds, where ERM colonization increased with bed age (Scagel, 2003). In Wisconsin, the youngest cranberry beds sampled had the highest ERM colonization $(60.7 \% \pm 1.2 \%$ root length colonized at 4 months after planting; Fig. 3). In Oregon, the youngest Oregon cranberry beds had the lowest ERM colonization $\mathbf{7 . 5 \%}$ in the $0-10$-year age class, with no effect of sampling date; Scagel, 2003).

The slight decline in root length colonization with increasing bed age in Wisconsin samples was puzzling, but may be explained by our observations on the effects of layer depth on ERM colonization (Fig. 4). The number of organic layers within the 15-cm-deep soil cores increased as bed age increased (Fig. 2). By mixing roots within a core before sampling for measurements of mycorrhizal colonization in the large-scale survey (Fig. 3), we confounded bed age with the number of layers sampled in a bed. The number of layers, and thus the average layer depth of the roots sampled in a bulked $15-\mathrm{cm}$ core sample increased with increasing bed age (Fig. 2). Because of the negative correlation between layer depth and ERM colonization seen in intact cores (Fig. 4), we would expect a negative correlation between bed age and ERM colonization even in the absence of a direct effect of bed age per se on colonization.

Our observations of the pronounced effect of layer depth on ERM colonization (Fig. 4) raised questions about our survey data, which were derived from bulked, mixed root samples, and therefore included multiple layers. Variation resulting from layering was not present in beds younger than 6 years old. Although beds may be sanded in years 1 and 2 to bury runners and force production of uprights, there is not sufficient cranberry biomass during these early stages of bed establishment to produce layers of organic matter. In contrast, the potential for underestimating the extent of ERM colonization in the oldest cranberry beds was high, as a result of the mixing of highly colonized upper layers with less colonized lower layers. The influence of this additional error on our analysis can be determined by comparing variance components as a function of bed age. Core-to-core variation within a bed was as great in young, unlayered beds as in older, layered beds (data not shown). These unexplained sources of core-to-core variation are likely to exceed variation as a result of combining layers within bulked samples. Future surveys of cranberry mycorrhizal colonization in layered soils should be carried out with sampling from the top layer, unless further analyses of layer-bytreatment interactions are desired.

The negative correlation between layer depth and ERM colonization found in most samples (Fig. 4) was likely the result of effects of litter decomposition on one or more aspects of the symbiosis; deeper layers include older, more decomposed leaf litter, with a lower C-to-N ratio (Fig. 5). Changes in litter C-to$\mathrm{N}$ ratio or in the quality of litter carbon available to decomposers may have altered fungal community composition (e.g., Thormann et al., 2003). Forest soil ectomycorrhizal fungal communities have been observed to differ with depth (and probably litter age) in the soil (Dickie et al., 2002); detailed examination of the ERM communities in layered cranberry soils may reveal similar patterns.

The susceptibility of roots to colonization may also have been indirectly affected by the shift in litter quality during decomposition. Microbial immobilization of $\mathrm{N}$ mineralized from organic matter is greatest in litter with a high $\mathrm{C}$-to- $\mathrm{N}$ ratio. With a decreased litter $\mathrm{C}$-to- $\mathrm{N}$ ratio (deeper layers), any inorganic $\mathrm{N}$ present in the soil is expected to be more available (Booth et al., 2005). As a result of the decline in C-to-N ratio with depth (Fig. 5), $\mathrm{N}$ availability should be greater in deeper, more decomposed layers. Colonization observed in vitro has been shown to decrease with increased $\mathrm{N}$ availability (Read and Bajwa, 1985) (K.R. Kosola and B.A.A. Workmaster, unpublished data). Variation in cranberry root age and function with depth has not been explored, but may also effect ERM colonization.

We did not find a negative correlation between soil layer depth and colonization in all samples (Fig. 4). This 


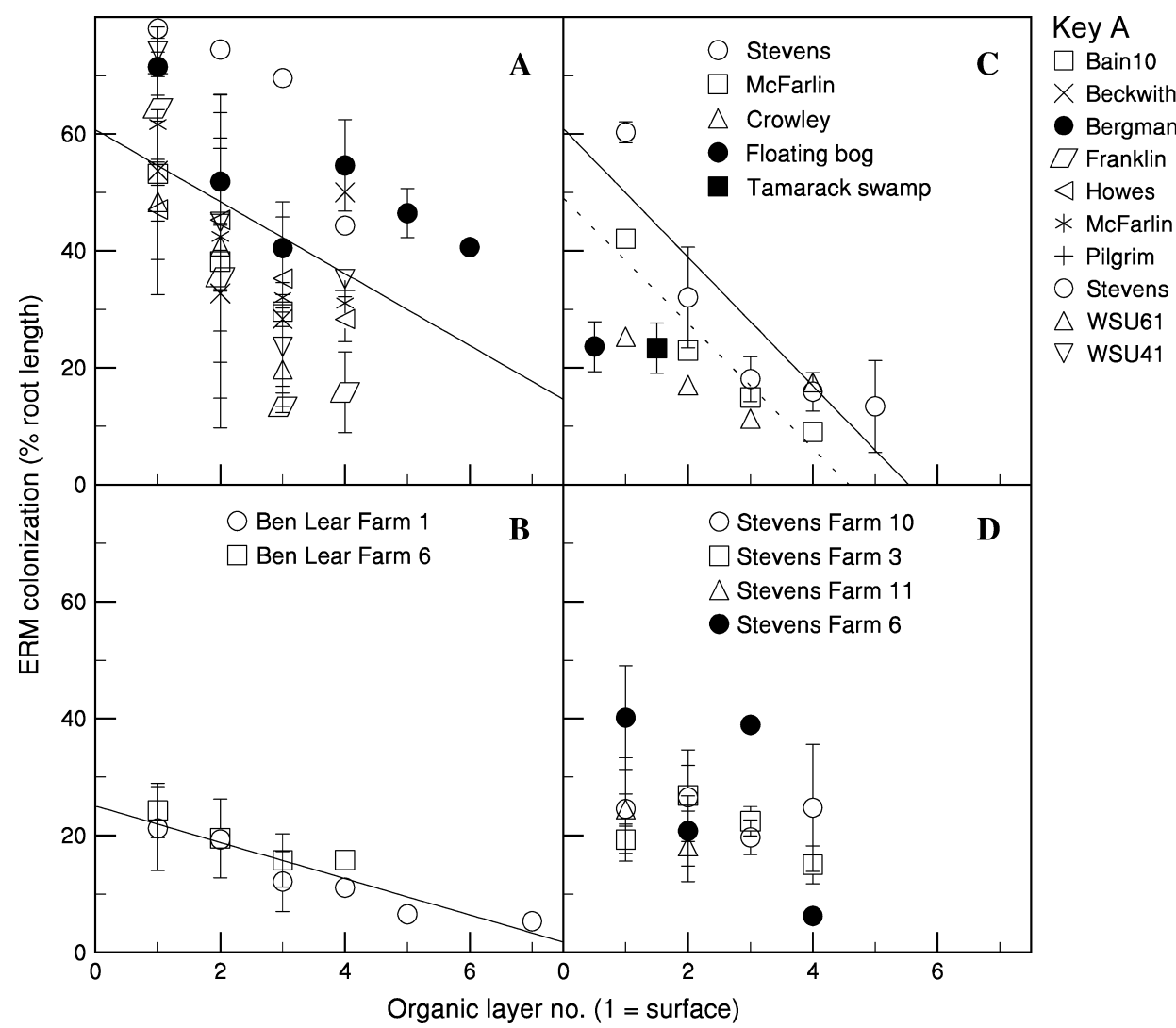

Fig. 4. Effect of soil organic layer depth on ericoid mycorrhizal (ERM) colonization (percent root length) of cranberry. (A) Soil cores collected from a single cultivar trial, June 2002 (farm 3, Table 3). Regression based on mean values for all cultivars at each depth. Colonization $=-6.2$ (layer) $+60.1, R^{2}=0.24$. (B) 'Ben Lear' soil cores collected June 2002 (farms 1 and 6, Table 3). Regression based on combined data from both locations. Colonization $=-3.1$ (layer) $+25, R^{2}=0.87$. (C) Soil cores collected Nov. 2004 (farm 9). 'Stevens' (solid line); colonization $=-11.0$ (layer) $+60.9, R^{2}=0.80$. 'McFarlin' (dashed line); colonization $=-10.7($ layer $)+50.0, R^{2}=$ 0.92. (D) Soil cores collected June 2004 (farms 3, 6, 10, and 11; Table 3). Values based on mean \pm SE. Lines only shown for significant regressions $(P \leq 0.05)$.

was not the result of cultivar effects. The correlation was absent in the 'Stevens' beds sampled in June 2004, but was clearly evident in a different set of 'Stevens' beds sampled in Nov. 2004 (Fig. 4). Depth effects on colonization are not uniformly found in other ericaceous communities. Johansson (2000) did not detect differences in ERM colonization of Calluna vulgaris (L.) Hull in a top, organic mor soil layer and an underlying bleached sand layer, although this was apparently the result of the substantial spatial variability in colonization.

Seasonal or year-to-year variation in colonization may be responsible for the variation in layer depth by colonization interactions seen in 2004, although site-specific effects seem more likely. Scagel (2003) found interactions between sampling date (March, May, and July vs. September and November) and ERM colonization in 'Stevens' beds sampled in Oregon. The variation between early-season and late-season samples was about $10 \%$; although significant, this was not a greater source of variation than found among and within beds in our samples. Seasonal variation in ERM colonization of about $15 \%$ has been found in wild C. vulgaris populations (Johansson 2000 ), similar to seasonal variation found in cultivated cranberry by Scagel (2003). Ericoid mycorrhizal colonization in an arctic mixed ericaceous community dominated by Vaccinium vitis-ideae L. and V. myrtillus L. varied during the year, and was positively correlated with ecosystem photosynthesis (Olsrud et al., 2004), which may play a role in seasonal variation in cranberry ERM colonization.

The lack of cultivar effects on colonization is striking in the Wisconsin samples. We are aware that cultivar identification and genetic uniformity within a bed may be uncertain for the older cultivars, particularly 'McFarlin' (Novy et al., 1994, 1996), but variation in colonization rates appears similar among cultivars of more recent origin (e.g., 'Pilgrim'; Roper and Vorsa, 1997) to that found in the older cultivars (Fig. 3). Selection for the ability to form ERM associations is likely to have been very high in the native environment of cranberries, because of their value in acquiring organic N (Read, 1983). Our limited sample from wild populations of cranberries in fall 2004 showed that colonization was present $(24 \%$ root length colonized on average; Fig. 4C), but not at the high values $(>90 \%$ colonization) found in ericaceous plants adjacent to cranberry beds in Oregon (Scagel, 2003).

Our data suggested that fungicide applications for fruit disease control did not suppress ERM colonization of cranberry. Neither of the Wisconsin farms where fungicides were applied (farms 5 and 9) had significantly lower levels of colonization than farms where fungicides were not applied (data not shown). It is not known whether fungicide applications for control of root diseases (e.g., root rot incited by Phytophthora cinnamomi Rands) would alter ERM colonization, although fungicides specific for oomycete fungi like Phytophthora de Bary are unlikely to have a direct effect on the basidiomycete and ascomycete fungi typically found in ERM communities (Allen et al., 2003).

In conclusion, ERM colonization was common throughout Wisconsin cranberry production. Combined with Scagel's findings in Oregon (Scagel 2003), our data indicate that there are unexplained regional differences in cranberry cultivation that affect the relationship between bed age and ERM colonization. Mycorrhizal cranberries in commercial production may be able to obtain some of their $\mathrm{N}$ from organic sources (Bajwa et al., 1985; Bajwa and Read, 1986; Read and Bajwa, 1985). There is ample organic matter present in Wisconsin cranberry beds that are more than 3 to 5 years old, because leaf litter accumulates quickly and decomposes slowly (Davenport and DeMoranville, 1993). Dissolved organic matter is also present in groundwater (D.S. Randhawa, B.A. Browne, S.M. Stackpoole, and K.R. Kosola, unpublished data), and in root zone soil solution (S.M. Stackpoole and K.R. Kosola, unpublished data). 


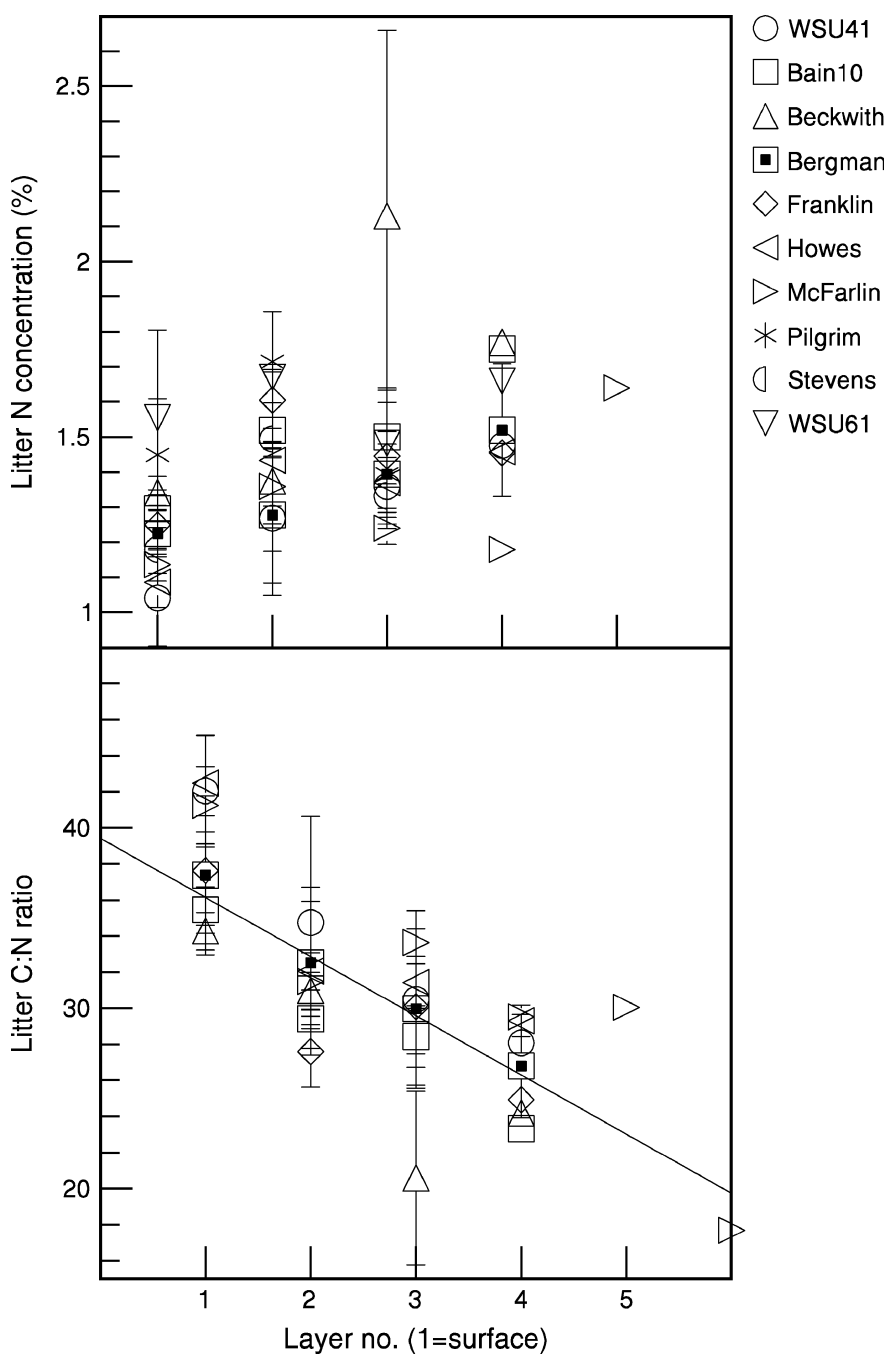

Fig. 5. Effects of soil organic layer depth on cranberry leaf litter composition in soil cores collected in July 2002 from a single bed containing a cultivar trial (farm 3; Fig. 4A). (A) Regression for layer depth versus percentage nitrogen (N) nonsignificant. (B) Regression for layer depth versus carbon (C)-to-N ratio. Carbon-to-N ratio $=39.42-3.28 \times$ layer, $R^{2}=0.44, P<0.0001$. Values based on mean \pm SE. Lines only shown for significant regressions $(P \leq 0.05)$.

It is not clear whether ERM fungi play a significant role in $\mathrm{N}$ nutrition in cultivated cranberries. Establishing the role of mycorrhizal utilization of organic $\mathrm{N}$ in cranberry $\mathrm{N}$ cycling is a reasonable goal in these agroecosystems. This work would be enhanced by characterization (e.g., Allen et al., 2003) of mycorrhizal community composition in cultivated and wild cranberry populations across North America.

\section{Literature Cited}

Allen, T.R., T. Millar, S.M. Berch, and M.L. Berbee. 2003. Culturing and direct DNA extraction find different fungi from the same ericoid mycorrhizal roots. New Phytol. 160:255-272.

Bajwa, R., S.M. Abuarghub, and D.J. Read. 1985. The biology of mycorrhiza in the Ericaceae. 10. The utilization of proteins and the production of proteolytic-enzymes by the mycorrhizal endophyte and by mycorrhizal plants. New Phytol. 101:469-486.

Bajwa, R. and D.J. Read. 1986. Utilization of mineral and amino-N sources by the ericoid mycorrhizal endophyte Hymenoscyphus ericae and by mycorrhizal and nonmycorrhizal seedlings of Vaccinium. Trans. Br. Mycol. Soc. 87:269-277.
Berch, S.M., T.R. Allen, and M.L. Berbee. 2002. Molecular detection, community structure and phylogeny of ericoid mycorrhizal fungi. Plant Soil 244:55-66.

Booth, M.S., J.M. Stark, and E. Rastetter. 2005. Controls on nitrogen cycling in terrestrial ecosystems: A synthetic analysis of literature data. Ecol. Monogr. 75:139-157.

Bremner, J.M. 1996. Nitrogen-Total, p. 1085-1121. In: D.L. Sparks (ed.). Methods of soil analysis. Part 3. Chemical methods. SSSA Book Ser. 5. SSSA, Madison, Wisc.

Byrne, K. and D.T. Mitchell. 2004. Responses of mycorrhizal and nonmycorrhizal Erica cinerea and Vaccinium macrocarpon to Glomus mosseae. Mycorrhiza 14:31-36.

Caruso, F.L. and D.C. Ramsdell. 1995. Compendium of blueberry and cranberry diseases. APS Press, St. Paul, Minn.

Davenport, J.R. and C.J. DeMoranville. 1993. A survey of several soil physical characteristics of cultivated cranberry bog soils in North America. Comm. Soil Sci. Plant Anal. 24:1769-1773.

Davenport, J.R. and C.J. DeMoranville. 2004. Temperature influences nitrogen release rates in cranberry soils. HortScience 39:80-83.

Davenport, J.R. and K.D. Patten. 2002. Nitrogen release in virgin and cultivated organic cranberry soils. Acta Hort. 574:341-346.

Dickie, I.A., B. Xu, and R.T. Koide. 2002. Vertical niche differentiation of ectomycorrhizal hyphae in soil as shown by T-RFLP analysis. New Phytol. 156:527-535.

Eck, P. 1990. The American cranberry. Rutgers University Press, New Brunswick, N.J.

Giovannetti, M. and B. Mosse. 1980. An evaluation of techniques for measuring vesicular-arbuscular infection in roots. New Phytol. 84:489-500.

Grace, C. and D.P. Stribley. 1991. A safer procedure for routine staining of vesicular-arbuscular mycorrhizal fungi. Mycol. Res. 95:1160-1162.

Hashem, A.R. 1995. The role of mycorrhizal infection in the resistance of Vaccinium macrocarpon to manganese. Mycorrhiza 5:289-291.

Johansson, M. 2000. The influence of ammonium nitrate on the root growth and ericoid mycorrhizal colonization of Calluna vulgaris (L.) Hull from a Danish heathland. Oecologia 123:418-424.

Leake, J.R., G. Shaw, and D.J. Read. 1990. The role of ericoid mycorrhizas in the ecology of ericaceous plants. Agr. Ecosys. Environ. 29:237-250.

Malmer, N., C. Albinsson, B.M. Svensson, and B. Wallen. 2003. Interferences between sphagnum and vascular plants: Effects on plant community structure and peat formation. Oikos 100: 469-482.

Myers, M.D. and J.R. Leake. 1996. Phosphodiesters as mycorrhizal P sources. 2. Ericoid mycorrhiza and the utilization of nuclei as a phosphorus and nitrogen source by Vaccinium macrocarpon. New Phytol. 132:445-451.

Nelson, D.W. and L.E. Sommers. 1996. Total carbon, organic carbon, and organic matter, p. 961-1010. In: D.L. Sparks (ed.). Methods of soil analysis. Part 3. 3rd ed. SSSA Book Ser. 5. SSSA, Madison, Wisc.

Novy, R.G., C. Kobak, J. Goffreda, and N. Vorsa. 1994. RAPDS identify varietal misclassification and regional divergence in cranberry [Vaccinium macrocarpon (Ait) Pursh]. Theor. Appl. Genet. 88:1004-1010.

Novy, R.G., N. Vorsa, and K. Patten. 1996. Identifying genotypic heterogeneity in 'McFarlin' cranberry: A randomly-amplified polymorphic DNA (RAPD) and phenotypic analysis. J. Amer. Soc. Hort. Sci. 121:210-215.

Olsrud, M., J.M. Melillo, T.R. Christensen, A. Michelsen, H. Wallander, and P.A. Olsson. 2004. Response of ericoid mycorrhizal colonization and functioning to global change factors. New Phytol. 162:459-469.

Read, D.J. 1983. The biology of mycorrhiza in the Ericales. Can. J. Bot. 61:985-1004.

Read, D.J. 1996. The structure and function of the ericoid mycorrhizal root. Ann. Bot. (Lond.) 77:365-374. 
Read, D.J. and R. Bajwa. 1985. Some nutritional aspects of the biology of ericaceous mycorrhizas. Proc. Royal Soc. Edinburgh Sect. B- Biol. Sci. 85:317-332.

Roper, T.R. and N. Vorsa. 1997. Cranberry: Botany and horticulture. Hort. Rev. (Amer. Soc. Hort. Sci.) 21:215-249.

Scagel, C.F. 2003. Mycorrhizal status of sand-based cranberry (Vaccinium macrocarpon) bogs in southern Oregon. Small Fruit Rev. 2:31-41.

Straker, C.J. and D.T. Mitchell. 1986. The activity and characterization of acid phosphatases in endomycorrhizal fungi of the Ericaceae. New Phytol. 104:243-256.

Stribley, D.P. and D.J. Read. 1976. The biology of mycorrhiza in the Ericaceae. VI. The effects of mycorrhizal infection and concentration of ammonium nitrogen on growth of cranberry (Vaccinium macrocarpon Ait.) in sand culture. New Phytol. 77:63-72.
Stribley, D.P. and D.J. Read. 1980. The biology of mycorrhiza in the Ericaceae. VII. The relationship between mycorrhizal infection and the capacity to utilize simple and complex organic nitrogen sources. New Phytol. 86:365-371.

Stribley, D.P., D.J. Read, and R. Hunt. 1975. The biology of mycorrhiza in the Ericaceae. V. The effects of mycorrhizal infection, soil type and partial soil-sterilization (by gamma-irradiation) on growth of cranberry (Vaccinium macrocarpon Ait.). New Phytol. 75:119-130.

Svensson, B.M. 1995. Competition between Sphagnum fuscum and Drosera rotundifolia: A case of ecosystem engineering. Oikos 74:205-212.

Thormann, M.N., R.S. Currah, and S.E. Bayley. 2003. Succession of microfungal assemblages in decomposing peatland plants. Plant Soil 250:323-333. 